\title{
PLASMA LIPIDS IN CHRONIC HEMORRHAGIC NEPHRITIS
}

\author{
BY IRVINE H. PAGE, ESBEN KIRK, AND DONALD D. VAN SLYKE \\ (From the Hospital of the Rockefeller Institute for Medical Research, New York)
}

(Received for publication October 7, 1935)

That lipemia is frequent in renal disease was noted by Bright and his colleagues. Christison (1839), who in Edinburgh at once began to extend the studies begun by Bright in London, states that "In the early stage the serum is usually somewhat lactescent, and yields to sulfuric ether when agitated with it a small quantity of concrete oily matter, which seems to differ little from the fat of cellular tissue." Christison also noted that in the same stage of the disease the specific gravity and albumin content of the plasma were low. The " early stage" of Christison apparently includes what is now termed by Addis and others the chronic active stage. The two most striking serum changes, protein deficit and liquid excess, that occur in this stage, with its usual "nephrotic" character, were clearly recognized by the early observers. Evidence concerning the types of lipids and proteins affected, and the extent of their changes during the course of the disease, necessarily awaited later methods of analysis.

The earlier quantitative studies, on unclassified cases of Bright's disease, merely showed that samples of plasma from a considerable proportion of nephritic patients had high total lipid or cholesterol values (Chauffard, Laroche, and Grigaut, 12 cases (1911); Widal, Weill, and Laudat (1912) ; Denis, 30 cases (1917)). Gainsborough (1929) confirmed these results with regard to cholesterol by the gravimetric digitonin method, and determined both free and esterified cholesterol.

Evidence that high plasma cholesterol is characteristic of the nephrotic type or stage of Bright's disease was furnished by Epstein (1917), who published data from 66 renal and cardiac cases, of which 24 were of the nephrotic type. All cases of this type showed total colorimetric cholesterol values markedly above normal, while no other cases did. Confirmative results from 2 cases of nephrotic and 21 of non-nephrotic Bright's disease were published by Port (1919), from 5 cases of nephrosis and 13 of glomerulonephritis by Hahn and Wolff (1921), and from 17 cases of nephro- sis by Schwarz and Kohn (1922). Westphal (1924-5) found high serum total cholesterol (250 to $430 \mathrm{mgm}$.) in 2 cases of amyloid nephrosis. Murphy (1927) and Maxwell (1927-28; 1934) found increased plasma cholesterol in cases of nephritis with edema, but not as a rule in those without it. Lichtenstein and Epstein (1931) found both free and esterified cholesterol increased in nephrosis and in glomerular nephritis with edema. They also found that the proportion of cholesterol in the form of esters was increased to 80 to 90 per cent (compared with the usual normal of 60 to 70 per cent). With regard to the high proportion of esterified cholesterol their results are at variance with those of Gainsborough (1929) and the present writers.

Calvin and Goldberg (1931) found that, while cholesterolemia developed with nephritic edema, it sometimes continued for a year or more after the edema disappeared.

That, on the other hand, in the terminal stage of advanced nephritis, plasma total cholesterol is usually not above the normal range, and may fall to the lower part of this range during the last days or weeks, was found by Henes (1920) and by Ashe and Bruger (1933). In the intermediate chronic stage these authors found plasma cholesterol values either within or above the normal range. They believed that in an advanced case with nitrogen retention, a fall of plasma cholesterol was a grave prognostic sign.

Concerning the behavior of the lipids other than cholesterol the data have been conflicting. Bloor (1917), in a series of 23 unclassified renal cases, found that in most of them the total fatty acids were high, while cholesterol and phosphatides were normal, the high fatty acids apparently being due to high neutral fats. On the other hand, Daniels (1925) in 5 out of 7 nephrotic cases (chronic parenchymatous) found increases, not only in the total fatty acids, but also in the phosphatides and the cholesterol. Hoesch (1931) found high phosphatides in chronic nephritis. Knauer (1927) 
stated that in 15 cases of nephrosis he found increases of all 3 lipid fractions, but gave the figures for only one case. Ling and Liu (1928) studied 5 nephrotic cases, in which they determined total fatty acids and unsaponifiable matter (mostly cholesterol), and found increased values for these two fractions which averaged respectively 310 and 170 per cent of the average normal.

Hiller, Linder, Lundsgaard, and Van Slyke (1924) reported abnormally high plasma total cholesterol and fatty acids in 3 cases of nephrosis and 3 of chronic active hematuric nephritis. Also, when 1 gram of butter per kilo was ingested these patients showed greater increase, both absolute and percentage, in plasma fatty acids than was shown by normal subjects. The respiratory quotient fell as much or more than in normal subjects after similar butter ingestion, indicating that the lipemic patients showed no delay or deficiency in their ability to burn fat. It was concluded that their lipemia might be due to a disturbance in the mechanism for transferring lipids from the blood to the tissue depots.

The cases of Daniels (1925) and of Hiller, Linder, Lundsgaard and Van Slyke (1924) are described, but clinical data for characterization of the type and stage of renal disease in the cases of most of the other authors quoted are either scanty or lacking.

Ling and Liu (1928) and Gainsborough (1929) used gravimetric methods, but the analyses of other authors have been chiefly by colorimetric or nephelometric technique, presumably inferior in accuracy either to the methods now employed in Bloor's and Peters' laboratories or to the present gasometric procedures.

Concerning the question of the relative behavior of the different plasma lipids in the different types and stages of Bright's disease, it is evident that previous analytical data are conflicting, and that the clinical description of most of the reported cases has been too scanty to afford accurate characterization of the type and stage of the disease. We have therefore determined the different lipids in a series of cases under observation in this hospital.

\section{METHODS AND CALCULATIONS}

The gasometric methods of Kirk, Page, and Van Slyke (1934) were used for determining the lipids. The blood was drawn before breakfast and handled as described by these authors.

From the directly determined data in Tables I $A$ and II $A$ the cholesterol esters, phosphatides, neutral fats, and total lipids, used in computing Tables I $B$ and II $B$, were calculated as described by Page, Kirk, Lewis, Thompson, and Van Slyke (1935). The formulae used are:
Total lipids $=$ Total lipid carbon $\times 1.3$
Phosphatides $=$ Lipid phosphorus $\times 23.5$
Cholesterol esters $=$ Esterified cholesterol $\times 1.69$
Neutral fats $=$ (Total lipids) - [Free cho-
lesterol) + (Cholesterol esters) + (Phospha- tides) ].

As pointed out by the above authors, the " neutral fat" fraction thus calculated contains some material besides the simple tri-glycerides.

\section{CASES STUDIED}

The plasma lipids have been determined once or more in each of 13 cases of hemorrhagic Bright's disease, of which 7 were in the chronic active, and 6 in the terminal stage. In classifying the cases we have followed the usage of Van Slyke, Stillman, Möller, et al. (1930). The chronic active cases are classified as those which have passed the initial stage and apparently become chronic, but in which the renal function has not fallen far enough to depress the urea clearance consistently below 20 per cent of the average normal value. The terminal cases are those in which the clearance has fallen permanently below 20 per cent of normal. As pointed out by Van Slyke, Stillman, Möller, et al., the chronic active or intermediate stage is usually dominated by the signs of the nephrotic syndrome, viz., edema, heavy proteinuria, and plasma protein deficit; but with passage into the terminal stage these signs to a varying degree recede, and hypertension, cardiac enlargement, and eye-ground changes are likely to become prominent.

The cases in Tables $\mathrm{I} A, \mathrm{I} B$, and $\mathrm{I} C$ are fairly characteristic of the chronic active stage. The nephrotic syndrome was prominent in all except Number 6. Cases 1 and 2 could be mistaken for pure nephrosis, were it not for their histories.

In Tables II $A$, II $B$, and II $C$ are given analytical and clinical data from six cases representing different degrees of progress in the terminal stage. 
TABLE IA

Chronic active stage of hemorrhagic Bright's disease, with nephrotic syndrome

Cases are arranged in order of increasing severity, according to urea clearance (see Table $\mathrm{I} C$ ). Lipid concentrations are in mgm. per $100 \mathrm{cc}$. plasma. Normal range for comparison is given at bottom of table.

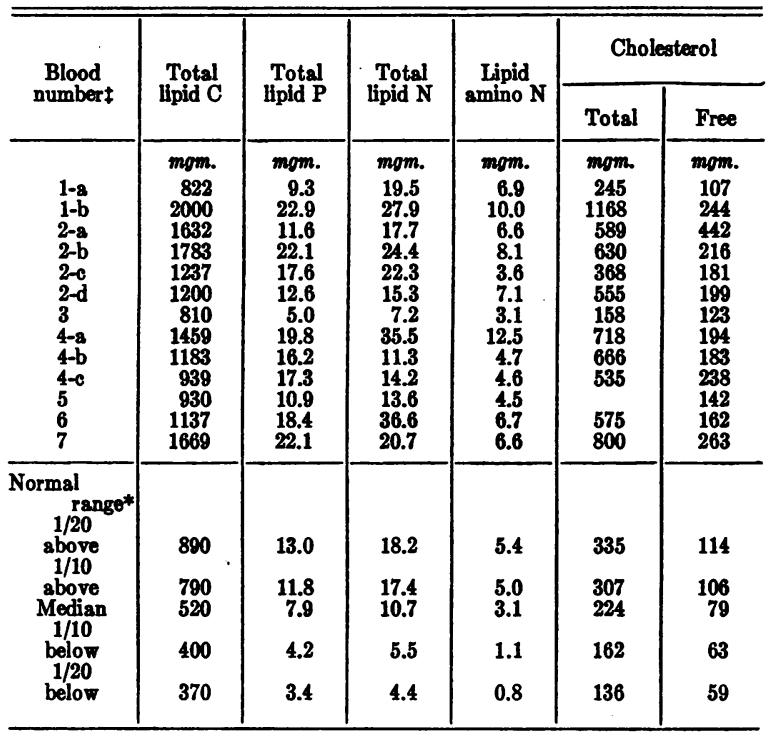

$\$$ Bloods 1 -a and 1-b are from Patient Number 1, etc.

* From Page, Kirk, Lewis, Thompson, and Van Slyke (1935). For more complete normal data see original. The figures on the line marked " $1 / 20$ above" are those at such levels that, according to the data of these authors, only 1 normal subject in 20 would show higher lipid concentrations. The figures on the succeeding lines are of similar significance.
TABLE IB

Composition of plasma lipid mixture

\begin{tabular}{|c|c|c|c|c|c|c|c|}
\hline \multirow[b]{2}{*}{$\begin{array}{c}\text { Blood } \\
\text { number }\end{array}$} & \multicolumn{4}{|c|}{ Percentage of total lipids as } & \multirow{2}{*}{$\begin{array}{c}\text { Per- } \\
\text { oentage } \\
\text { of } \\
\text { total } \\
\text { choles- } \\
\text { terol } \\
\text { esteri- } \\
\text { fied }\end{array}$} & \multirow{2}{*}{$\frac{\text { Total N }}{\begin{array}{c}\mathbf{P} \\
\text { atomic } \\
\text { ratio }\end{array}}$} & \multirow{2}{*}{ 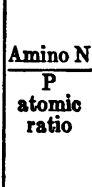 } \\
\hline & $\begin{array}{c}\text { Free } \\
\text { choles- } \\
\text { terol }\end{array}$ & $\begin{array}{c}\text { Choles } \\
\text { terol } \\
\text { esters }\end{array}$ & $\begin{array}{l}\text { Phos- } \\
\text { phs- } \\
\text { tides }\end{array}$ & $\begin{array}{l}\text { Neutral } \\
\text { fat + } \\
\text { unidenti- } \\
\text { fied } \\
\text { lipids }\end{array}$ & & & \\
\hline $\begin{array}{l}1-a \\
1-b \\
2-a \\
2-b \\
2-c \\
2-d \\
3 \\
4-a \\
4-b \\
4-c \\
5 \\
6 \\
7\end{array}$ & $\begin{array}{c}\text { per cent } \\
10 \\
9 \\
21 \\
9 \\
11 \\
13 \\
12 \\
10 \\
12 \\
20 \\
12 \\
11 \\
12 \\
\end{array}$ & $\begin{array}{c}\text { per cent } \\
22 \\
62 \\
12 \\
30 \\
19 \\
39 \\
6 \\
47 \\
54 \\
41 \\
48 \\
42 \\
\end{array}$ & $\begin{array}{c}\text { per cent } \\
20 \\
21 \\
13 \\
22 \\
25 \\
19 \\
11 \\
25 \\
25 \\
33 \\
21 \\
29 \\
24\end{array}$ & $\begin{array}{c}\text { per cent } \\
48 \\
7 \\
54 \\
38 \\
44 \\
29 \\
71 \\
17 \\
9 \\
5 \\
12 \\
21\end{array}$ & \begin{tabular}{|c|} 
per cent \\
56 \\
79 \\
25 \\
66 \\
51 \\
64 \\
22 \\
73 \\
73 \\
55 \\
72 \\
67
\end{tabular} & $\begin{array}{l}4.6 \\
2.7 \\
3.4 \\
2.4 \\
2.8 \\
2.7 \\
3.2 \\
4.0 \\
1.5 \\
1.8 \\
2.8 \\
4.4 \\
2.1\end{array}$ & $\begin{array}{l}1.64 \\
0.97 \\
1.26 \\
0.81 \\
0.45 \\
1.25 \\
1.37 \\
1.40 \\
0.64 \\
0.59 \\
1.50 \\
0.81 \\
0.66\end{array}$ \\
\hline Mean & 12 & 36 & 22 & 30 & 59 & 3.0 & 0.99 \\
\hline $\begin{array}{l}\text { Standard } \\
\text { deviation }\end{array}$ & \pm 3.8 & \pm 17 & \pm 5.9 & \pm 21 & \pm 18 & \pm 1.0 & \pm 0.43 \\
\hline $\begin{array}{c}\text { Normal* } \\
\text { mean }\end{array}$ & 11.8 & 35.4 & 23.6 & 28.2 & 63.1 & 3.4 & 1.00 \\
\hline $\begin{array}{l}\text { Normal* } \\
\text { standaard } \\
\text { deviation }\end{array}$ & \pm 3.8 & \pm 10.3 & \pm 6.4 & \pm 11.3 & \pm 8.3 & \pm 1.5 & \pm 0.53 \\
\hline
\end{tabular}

Plasma lipids in the chronic active stage of hemorrhagic nephritis

Lipid concentrations. Table I $A$ shows that the total lipids in all the cases examined were between 1 and 2.6 grams per $100 \mathrm{cc}$. of plasma. Since 1 gram per $100 \mathrm{cc}$. is reached by only about 1 nor-

TABLE IC

Clinical data on patients reported in Tables IA and IB

\begin{tabular}{|c|c|c|c|c|c|c|c|c|c|c|c|c|c|}
\hline \multirow{2}{*}{$\begin{array}{c}\text { Series } \\
\text { and } \\
\text { blood } \\
\text { number }\end{array}$} & \multirow{2}{*}{$\begin{array}{l}\text { Hospital } \\
\text { number }\end{array}$} & \multirow{2}{*}{$\begin{array}{l}\text { Age } \\
\text { and } \\
\text { sex }\end{array}$} & \multirow{2}{*}{ Date } & \multirow{2}{*}{$\begin{array}{c}\text { Blood } \\
\text { pressure }\end{array}$} & \multirow{2}{*}{$\begin{array}{l}\text { Urine } \\
\text { proteins } \\
\text { per } \\
24 \text { hours }\end{array}$} & \multirow{2}{*}{$\begin{array}{l}\text { Blood } \\
\text { ures N } \\
\text { per } \\
100 \text { oc. }\end{array}$} & \multirow{2}{*}{$\begin{array}{c}\text { Urea } \\
\text { clearance }\end{array}$} & \multirow{2}{*}{$\begin{array}{l}\text { Hemo- } \\
\text { globin }\end{array}$} & \multicolumn{3}{|c|}{ Proteins per $100 \mathrm{cc}$. plasms } & \multirow{2}{*}{ Edema } & \multirow{2}{*}{$\begin{array}{l}\text { Red blood } \\
\text { cells in } \\
\text { 12-hour } \\
\text { urine }\end{array}$} \\
\hline & & & & & & & & & Globulin & Albumin & Total & & \\
\hline $\begin{array}{l}1-a \\
1-b \\
2-a \\
2-b \\
2-c \\
2-d \\
3 \\
4-a \\
4-b \\
4-c \\
5 \\
6 \\
7\end{array}$ & $\begin{array}{l}7049 \\
7049 \\
9246 \\
9246 \\
9246 \\
9246 \\
8658 \\
9279 \\
9279 \\
9279 \\
9040 \\
9172 \\
8936\end{array}$ & $\begin{array}{l}\text { years } \\
27 \mathrm{M} \\
27 \mathrm{M} \\
20 \mathrm{~F} \\
20 \mathrm{~F} \\
20 \mathrm{~F} \\
20 \mathrm{~F} \\
19 \mathrm{~F} \\
22 \mathrm{~F} \\
22 \mathrm{~F} \\
22 \mathrm{~F} \\
42 \mathrm{M} \\
41 \mathrm{~F} \\
24 \mathrm{~F}\end{array}$ & $\begin{array}{lr}\text { March } & 19,1934 \\
\text { November } 23,1933 \\
\text { October } & 7,1933 \\
\text { December } & 1,1933 \\
\text { January } & 26,1934 \\
\text { May } & 24,1934 \\
\text { February } & 22,1934 \\
\text { December } & 5,1933 \\
\text { March } & 16,1934 \\
\text { June } & 26,1934 \\
\text { April } & 13,1934 \\
\text { April } & 2,1934 \\
\text { February } & 28,1934\end{array}$ & $\begin{array}{l}m m . H g \\
\\
114 / 66 \\
134 / 84 \\
138 / 90 \\
148 / 98 \\
150 / 102 \\
146 / 90 \\
168 / 106 \\
138 / 92 \\
155 / 96 \\
160 / 108 \\
154 / 88 \\
120 / 72 \\
130 / 94\end{array}$ & $\begin{array}{c}\text { grams } \\
15 \\
15 \\
16 \\
20 \\
12 \\
9 \\
9 \\
11 \\
14 \\
7 \\
5 \\
9 \\
10\end{array}$ & $\begin{array}{c}\text { mom. } \\
20 \\
19 \\
7 \\
9 \\
15 \\
21 \\
9 \\
40 \\
32 \\
27 \\
13 \\
44 \\
39\end{array}$ & $\begin{array}{c}\text { per cent of } \\
\text { averege } \\
\text { normal } \\
78 \\
91 \\
77 \\
68 \\
56 \\
56 \\
45 \\
54 \\
36 \\
34 \\
28 \\
30 \\
27 \\
17-24\end{array}$ & $\begin{array}{c}\text { per cent* } \\
82 \\
82 \\
85 \\
88 \\
91 \\
91 \\
86 \\
67 \\
75 \\
75 \\
70 \\
76 \\
66 \\
69\end{array}$ & $\begin{array}{c}\text { grams } \\
2.0 \\
3.3 \\
2.8 \\
\\
2.4 \\
2.8 \\
3.0 \\
2.3 \\
2.7\end{array}$ & $\begin{array}{c}\text { grams } \\
1.7 \\
1.4 \\
1.4 \\
\\
2.0 \\
2.0 \\
2.2 \\
2.2 \\
1.63\end{array}$ & $\begin{array}{c}\text { grams } \\
3.7 \\
3.7 \\
4.2 \\
4.0 \\
4.6 \\
4.4 \\
4.1 \\
4.8 \\
5.2 \\
5.2 \\
4.5 \\
6.1 \\
4.3\end{array}$ & $\begin{array}{l}+++ \\
++++ \\
+++ \\
++ \\
+ \\
0 \\
+++ \\
++ \\
+ \\
++ \\
++ \\
++\end{array}$ & $\begin{array}{c}15 \\
35 \\
111 \\
7 \\
1.3 \\
0 \\
0\end{array}$ \\
\hline
\end{tabular}

* 100 per cent hemoglobin $\approx 20.7$ volumes per cent $\mathrm{O}_{2}$ capacity in men, 19.0 in women (Peters and Van Slyke (1931), p. 544). 
TABLE IIA

Plasma lipid concentrations in terminal stage of hemorrhagic Bright's disease *

Cases are arranged in order of increasing severity, according to diminishing urea clearance.

\begin{tabular}{c|c|c|c|c|c|c}
\hline \hline $\begin{array}{c}\text { Blood } \\
\text { number }\end{array}$ & $\begin{array}{c}\text { Total } \\
\text { lipid C }\end{array}$ & $\begin{array}{c}\text { Total } \\
\text { lipld P }\end{array}$ & $\begin{array}{c}\text { Total } \\
\text { lipid N }\end{array}$ & $\begin{array}{c}\text { Lipid } \\
\text { amino N }\end{array}$ & \multicolumn{2}{|c}{ Cholesterol } \\
\cline { 4 - 6 } & & & & & Total & Froe \\
\hline & mom. & mgm. & mom. & mom. & mom. & mom. \\
8 & 835 & & & & 252 & 70 \\
9 & 850 & 9.6 & 14.0 & 4.6 & 395 & 134 \\
10 & 763 & 9.6 & 46.7 & 9.2 & 361 & 111 \\
$11-8$ & 849 & 8.1 & 30.6 & 7.3 & 296 & 105 \\
$11-b$ & 578 & 6.0 & 24.6 & 6.7 & 328 & 96 \\
12 & 488 & 5.8 & 25.6 & 6.3 & 241 & 96 \\
$13-8$ & 360 & 3.2 & 26.6 & 6.9 & 139 & 56 \\
$13-b$ & 321 & 3.0 & 7.5 & 1.2 & 152 & 56 \\
$13-c$ & 330 & 1.9 & 5.9 & 2.1 & 122 & 56 \\
& & & & & &
\end{tabular}

* For normal ranges, see bottom of Table I $A$.

TABLE IIB

Composition of plasma lipid mixture*

\begin{tabular}{|c|c|c|c|c|c|c|c|}
\hline \multirow{2}{*}{$\begin{array}{c}\text { Blood } \\
\text { number }\end{array}$} & \multicolumn{4}{|c|}{ Percentage of total lipids as } & \multirow{2}{*}{$\begin{array}{c}\text { Per- } \\
\text { centage } \\
\text { of } \\
\text { total } \\
\text { choles- } \\
\text { terol } \\
\text { esteri- } \\
\text { fied }\end{array}$} & \multirow{2}{*}{$\frac{\text { Total N }}{\begin{array}{c}\mathbf{P} \\
\text { atomio } \\
\text { ratio }\end{array}}$} & \multirow{2}{*}{$\frac{\text { Amino N N }}{\begin{array}{c}\mathbf{P} \\
\text { ramic } \\
\text { ratio }\end{array}}$} \\
\hline & $\begin{array}{c}\text { Free } \\
\text { choles } \\
\text { terol }\end{array}$ & $\begin{array}{c}\text { Choles } \\
\text { terol } \\
\text { esters }\end{array}$ & $\begin{array}{l}\text { Phos- } \\
\text { pha- } \\
\text { tdes }\end{array}$ & $\begin{array}{c}\text { Neutral } \\
\text { fat }\end{array}$ & & & \\
\hline $\begin{array}{l}8 \\
9 \\
10 \\
11-\mathrm{a} \\
11-\mathrm{b} \\
12 \\
13-8 \\
13-\mathrm{b} \\
13-6\end{array}$ & $\begin{array}{c}\text { per cent } \\
6 \\
12 \\
11 \\
10 \\
13 \\
16 \\
12 \\
13 \\
13\end{array}$ & $\begin{array}{c}\text { per cont } \\
28 \\
40 \\
43 \\
29 \\
53 \\
40 \\
30 \\
39 \\
26\end{array}$ & $\begin{array}{c}\text { per cont } \\
21 \\
23 \\
23 \\
17 \\
19 \\
20 \\
16 \\
17 \\
11\end{array}$ & $\begin{array}{c}\text { per cont } \\
\\
27 \\
23 \\
44 \\
14 \\
24 \\
42 \\
29 \\
50\end{array}$ & $\begin{array}{c}\text { per cont } \\
72 \\
66 \\
69 \\
66 \\
71 \\
60 \\
60 \\
63 \\
54\end{array}$ & $\begin{array}{r}3.2 \\
10.7 \\
8.4 \\
9.1 \\
9.7 \\
18.3 \\
6.5 \\
6.8\end{array}$ & $\begin{array}{l}1.1 \\
2.1 \\
2.0 \\
2.5 \\
2.4 \\
4.7 \\
0.9 \\
2.4\end{array}$ \\
\hline Mean & 12 & 35 & 18 & 82 & 64 & 9.0 & 2.5 \\
\hline $\begin{array}{l}\text { Standard } \\
\text { devistion }\end{array}$ & \pm 2.7 & \pm 8.9 & \pm 3.7 & \pm 12.4 & \pm 5.9 & \pm 4.5 & \pm 1.2 \\
\hline
\end{tabular}

* For normal means and standard deviations see bottom of Table II $B$. mal plasma out of 10 , it is evident that definite lipemia is the rule in this stage of nephritis, with total lipids varying upwards from the highest zone of the normal range.

Composition of the lipid mixture. The increase as a rule affects all the observed lipid fractions, including the petroleum-ether soluble, "lipid" nitrogen. Table I $B$ shows that in its composition the lipid mixture in these nephritic plasmas showed no characteristic difference from the mixture in normal plasma. The reciprocal variation of cholesterol esters and neutral fats noted in normal plasma (Page, Kirk, Lewis, Thompson, and Van Slyke (1935), p. 630) is more marked in this nephritic series, as indicated by the high standard deviations for cholesterol esters and neutral fats in Table $\mathrm{I} B$. The number of cases is not sufficient, however, to show whether the apparent increased variance is characteristic of lipemic nephritis, or is merely due to the chance occurrence, among the 13 plasmas reported, of 3 or 4 showing unusual deviations of the cholesterol ester : neutral fat ratio from the mean.

The results in Table $\mathrm{I} B$, like those of Gainsborough (1929), fail to show any tendency for the ratio, esterified cholesterol : total cholesterol, to increase in the lipemia of nephritis.

One behavior, noted by Page, Kirk, Lewis, Thompson, and Van Slyke (1935) in normal plasmas with unusually high lipid contents, is not apparent in the nephritic plasmas of Table I. In normal plasmas with lipid concentrations in the upper range these authors observed a tendency for

TABLE IIC

Terminal stage of hemorrhagic Bright's disease

Clinical data on subjects in Tables II $A$ and II $B$

\begin{tabular}{|c|c|c|c|c|c|c|c|c|c|c|c|c|c|c|}
\hline \multirow{2}{*}{$\begin{array}{c}\text { Series } \\
\text { and } \\
\text { blood } \\
\text { number }\end{array}$} & \multirow{2}{*}{$\begin{array}{l}\text { Hospital } \\
\text { number }\end{array}$} & \multirow{2}{*}{$\begin{array}{l}\text { Age } \\
\text { and } \\
\text { ax }\end{array}$} & \multirow{2}{*}{\multicolumn{2}{|c|}{ Datet }} & \multirow{2}{*}{$\underset{\text { pressure }}{\text { Blood }}$} & \multirow{2}{*}{$\begin{array}{l}\text { Urine } \\
\text { protains } \\
\text { per } \\
24 \text { hours }\end{array}$} & \multirow{2}{*}{$\begin{array}{c}\text { Blood } \\
\text { urea N } \\
\text { per } \\
100 \propto 0 .\end{array}$} & \multirow{2}{*}{$\begin{array}{c}\text { Urea } \\
\text { olearance }\end{array}$} & \multirow{2}{*}{$\begin{array}{l}\text { Hemo- } \\
\text { globin" }\end{array}$} & \multicolumn{3}{|c|}{ Proteins per 100 oc. plasma } & \multirow{2}{*}{ Edema } & \multirow{2}{*}{$\begin{array}{l}\text { Red blood } \\
\text { cells in } \\
\text { 12-hour } \\
\text { urine }\end{array}$} \\
\hline & & & & & & & & & & Globulin & Albumin & Total & & \\
\hline $\begin{array}{l}8 \\
9 \\
10 \\
11-a \\
11-b \\
12 \\
13-a \\
13-b \\
13-b\end{array}$ & $\begin{array}{l}8742 \\
8883 \\
9231 \\
9270 \\
9270 \\
8916 \\
8982 \\
8982 \\
8982\end{array}$ & $\begin{array}{l}\text { yoare } \\
24 \mathrm{~F} \\
28 \mathrm{~F} \\
30 \mathrm{~F} \\
40 \mathrm{~F} \\
40 \mathrm{~F} \\
16 \mathrm{~F} \\
21 \mathrm{M} \\
21 \mathrm{M} \\
21 \mathrm{M}\end{array}$ & $\begin{array}{l}\text { Ootober } \\
\text { March } \\
\text { March } \\
\text { December } \\
\text { March } \\
\text { January } \\
\text { February } \\
\text { February } \\
\text { March }\end{array}$ & $\begin{array}{r}3,1938 \\
13,1934 \\
12,1934 \\
1,1933 \\
19,1934 \\
81,1934 \\
14,1934 \\
28,1934 \\
8,1934\end{array}$ & $\begin{array}{l}\operatorname{mm.~Ho} \\
216 / 166 \\
144 / 84 \\
220 / 114 \\
128 / 80 \\
160 / 92 \\
160 / 104 \\
168 / 96 \\
200 / 114 \\
196 / 116\end{array}$ & $\begin{array}{c}\text { grams } \\
2 \\
9 \\
3 \\
2 \\
1 \\
2 \\
17 \\
15 \\
12\end{array}$ & $\begin{array}{c}\text { mom. } \\
90 \\
72 \\
58 \\
51 \\
43 \\
43 \\
145 \\
146 \\
160 \\
238\end{array}$ & $\begin{array}{c}\text { per cont } \\
18 \\
17 \\
12 \\
7 \\
10 \\
6 \\
4 \\
6 \\
3\end{array}$ & $\begin{array}{c}\text { per cont } \\
96 \\
69 \\
62 \\
78 \\
76 \\
27 \\
81 \\
32\end{array}$ & $\begin{array}{c}\text { grems } \\
2.7 \\
2.5 \\
3.3 \\
2.4\end{array}$ & $\begin{array}{c}\text { grams } \\
2.6 \\
3.4 \\
3.0 \\
3.2\end{array}$ & $\begin{array}{c}\text { grams } \\
5.3 \\
5.9 \\
6.3 \\
5.7 \\
5.6 \\
5.8\end{array}$ & + & $\begin{array}{c}\text { millions } \\
++ \\
3.7 \\
1.9 \\
0.8 \\
0.1 \\
++ \\
++ \\
++ \\
++\end{array}$ \\
\hline
\end{tabular}

* 100 per cent hemoglobin $\approx 20.7$ volumes per cent $\mathrm{O}_{2}$ capacity in men, 19.0 in women (Peters and Van Slyke (1931), p. 544).

f Patient numbers 10,11, 12 and 13 have died on the following dates: Number 10, September 9, 1934; Number 11, April 25, 1935; Number 12, February 9, 1934; Number 13, April 17, 1934. 
the "neutral fats" (which include some unidentified petroleum-ether soluble material) to constitute a greater, and the cholesterol, both free and esterified, a lesser percentage of the lipid mixture than when the total lipid concentration was in the middle or lower normal ranges. If whatever factors caused this behavior in normal subjects acted in entirely the same way in nephritis, one would expect a higher proportion of neutral fats, and a lower proportion of free cholesterol and cholesterol esters, than the average in normal plasma. The limited number of cases reported in Table I fail to show such a tendency with any consistency.

While our data fail to show any consistent abnormalities in the composition of the lipid mixture of nephrotic plasma, Ling and Liu (1928) did find an abnormality in a property not determined in our analyses, viz., the degree of unsaturation. They found that the iodine number of the fatty acids in 5 nephrotic cases was only 59 to 97, compared with the normal average of 157 . The tendency for the iodine number to fall as lipemia increases, however, seemed not to be limited to lipemia of nephrotic origin. In 5 diabetics with lipemia Ling and Liu found iodine numbers as low (45 to 98) as in nephrosis.

Relation of plasma lipid and plasma protein concentrations. Both plasma protein deficit and lipemia are characteristic of the nephrotic syndrome, which is common in chronic active hemorrhagic nephritis (Van Slyke, Stillman et al. (1930)), and a fall in the proteins may accompany a simultaneous rise in lipids. In the individual cases, 1,2 , and 4 , in which repeated determinations were obtained over periods during which the plasma proteins showed definite rises, the lipids showed in each patient an accompanying decrease. However, when the entire group of Tables $\mathrm{I} A, \mathrm{I} B$, and $\mathrm{I} C$ is considered, it becomes evident that there is no close proportionality between the extents of lipemia and plasma protein deficit. Thus Case 3 showed the least lipemia, but nearly the greatest deficit in plasma proteins. Absence of consistent parallelism between lipemia and plasma protein deficit was also noted by Daniels (1925).
Plasma lipids in the terminal stage of hemorrhagic nephritis

Lipid concentrations. The cases in Table II may be divided into two groups, Cases 8, 9, 10, and 11 , which were not yet in uremia, and Cases 12 and 13 which were advanced to definite uremic symptoms. Cases 8, 9, 10, and the first observation on 11, show total lipid values in the range covered by the upper fifth of normal plasmas, and 3 of the 4 were in the range of the upper tenth of normal. In these cases there still existed a definite tendency towards lipemia, although not so marked as in the less advanced cases of Table I. The transition from the nephrotic syndrome of the chronic active stage to the vascular-uremic syndrome of the terminal stage is not sharp, and it is evident that some tendency to lipemia frequently persists, like other nephrotic signs, into the terminal stage.

However, the two cases, Numbers 12 and 13, which had advanced to uremia, showed no tendency towards lipemia. In fact all three observations on Case 13 showed lower plasma lipid content than was observed by Page, Kirk, Lewis, Thompson and Van Slyke (1935) in any of their 60 normal subjects.

Composition of the lipid mixture. Table IIB shows no consistent deviation from the normal, except in the nitrogen. The $\mathrm{N} / \mathrm{P}$ and Amino $\mathrm{N} / \mathrm{P}$ ratios average respectively 2.6 and 2.5 times higher than in normal plasma. Even more than in normal plasma the nitrogen soluble in petroleum ether exceeds the values which could be attributed to the phosphatides (Van Slyke, Page, Kirk, and Farr (1935)). In Cases 10 and 11 the lipid nitrogen approaches the urea nitrogen in concentration. There is evidently at times in the terminal stage of nephritis a marked tendency for accumulation of some unknown, petroleum-ether soluble nitrogenous product or products. The accumulation, although it may sometimes nearly equal, does not at all parallel that of urea. It is striking that during the month when Case 13 was under observation for plasma lipids, the lipid nitrogen fell from $26 \mathrm{mgm}$. to the low normal level of $6 \mathrm{mgm}$., while blood urea nitrogen rose from 148 to $238 \mathrm{mgm}$. The patient died a month after the last observation. It appears that the plasma lipid nitrogen, which is usually elevated in 
about the same proportion as the other lipids in the chronic active stage of hemorrhagic nephritis, may remain high in the terminal stage for some time after the other lipids have fallen, but that eventually the lipid nitrogen also may fall.

\section{Calculation of total lipids in lipemic plasma}

Page, Kirk, Lewis, Thompson, and Van Slyke (1935) have shown that, in normal plasma, total lipids can be calculated by the approximate formula, Total lipids $=1.3 \times$ Total lipid carbon, with practically the same results obtained by calculating the total lipids as the sum of phosphatides, free cholesterol, cholesterol esters, and neutral fats. The latter calculation is theoretically the more accurate, but the difference between total lipids calculated in the two respective ways was found in normal plasma to average less than 1 per cent of the values obtained. The accuracy of the 1.3 $X C$ formula is a matter of some importance, because its use enables one to estimate the total lipids from a single carbon determination on the petroleum ether extract.

In order to obtain data on the accuracy of this formula when applied to lipids in pathological, and particularly in lipemic, plasma, we have calculated the total lipids in both ways from the data in Tables I $A$ and II $A$. The 2 methods of calculation yield results agreeing in the pathological plasmas as closely as they were found to agree in normal plsama by Page, Kirk, Lewis, Thompson, and Van Slyke. It appears that one may use the $1.3 \times C$ formula for total lipids with fair assurance that the calculation error is practically within the limit of the analytical error, in pathological as well as normal plasma.

\section{SUM MARY}

The total lipids, in nephritic as well as in normal plasma, can be estimated from the total lipid carbon as $1.3 \times C$; the error involved in the use of the approximate factor 1.3 averages less than 1 per cent.

Single or repeated determinations of the different lipid fractions determinable by the gasometric method of Kirk, Page, and Van Slyke have been made on the plasmas of 13 patients with chronic hemorrhagic nephritis. The degree of renal dam- age varied from slight, with nearly normal urea clearance, to almost complete destruction, with only 3 per cent of normal clearance.

The results fit the following picture of the course of plasma lipid changes during the disease: In the chronic active stage (urea clearance over 20 per cent normal) there is a tendency to lipemia, with plasma lipids near or above the upper limit of normal levels; in the 7 cases reported in this stage, total lipids varied from 1 to 2.6 grams per 100 cc. of plasma, while normal subjects average 0.7 and seldom exceed 1.1. As the disease passes into the terminal stage (urea clearance under 20 per cent) the lipemia is likely to decrease, and before exitus the plasma lipid content may fall below normal. A similar course of total cholesterol change has been noted by Ashe and Bruger and by Henes. The present results indicate that it is followed also by the other lipids.

The individual lipid constituents, free cholesterol, cholesterol esters, phosphatides, and the neutral fat fraction, rise and fall together. The percentage of each in the lipid mixture, although variable, shows no characteristic trend of deviation from the percentage in normal plasma.

The amount of nitrogen soluble in petroleum ether also rises parallel with the other lipid constituents in the chronic active stage, but may not fall with them in the terminal stage. In consequence, the proportion of both total and amino nitrogen in the lipid mixture in the terminal stage averaged, in our cases, two to three times the proportion in normal plasma, or in the plasma from patients in the chronic active stage. The high atomic $N / P$ ratio, from 3 to 18 , in the terminal lipids is evidence that the nitrogen was chiefly in the form of petroleum-ether soluble substances other than the phosphatides.

The results, like those of Daniels, show no parallelism in severity between lipemia and plasma protein deficit, although both accompany the nephrotic syndrome.

\section{BIBLIOGRAPHY}

Ashe, B. I., and Bruger, M., The cholesterol content of the plasma in chronic nephritis and retention uremia. Am. J. M. Sc., 1933, 186, 670.

Bloor, W. R., The blood lipoids in nephritis. J. Biol. Chem., 1917, 31, 575. 
Calvin, J. K., and Goldberg, A. H., Cholesterol and edema. Their relationship in a group of children presenting the nephrotic syndrome. Am. J. Dis. Child., 1931, 41, 1066.

Chauffard, A., Laroche, G., and Grigaut, Le taux de la cholesterinémie au cours des cardiopathies chroniques et des néphrites chroniques. Compt. rend. Soc. de biol., 1911, 71, 108.

Christison, Robert, On Granular Degeneration of the Kidneys. Waldie, Philadelphia, 1839, p. 60.

Daniels, W. B., Plasma lipoids in renal disease. Brit. J. Exper. Path., 1925, 6, 283.

Denis, W., Cholesterol in human blood under pathological conditions. J. Biol. Chem., 1917, 29, 93.

Epstein, A. A., Concerning the causation of edema in chronic parenchymatous nephritis: method for its alleviation. Am. J. M. Sc., 1917, 154, 638.

Gainsborough, H., A study of so-called lipoid nephrosis. Quart. J. Med., 1929, 23, 101.

Hahn, A., and Wolff, E., Uber das Verhalten des Cholesterins im Blute von Nierenkranken. Ztschr. f. klin. Med., 1921, 92, 393.

Henes, E., Jr., The prognostic value of cholesterinemia in chronic nephritis. Arch. Int. Med., 1920, 25, 411.

Hiller, A., Linder, G. C., Lundsgaard, C., and Van Slyke, D. D., Fat metabolism in nephritis. J. Exper. Med., 1924, 39, 931.

Hoesch, K., Blutphosphatide und amine bei Nierenerkrankungen und ihre Beziehungen zum Hochdruck. Klin. Wchnschr., 1931, 10, 881.

Kirk, E., Page, I. H., and Van Slyke, D. D., Gasometric microdetermination of lipids in plasma, blood cells, and tissues. J. Biol. Chem., 1934, 106, 203.

Knauer, H., Ist die Nephrose eine Nierenerkrankung? Med. Klin., 1927, 23, 862.

Lichtenstein, L., and Epstein, E. Z., The blood lipoids in nephrosis and chronic nephritis with edema. Arch. Int. Med., 1931, 47, 122.

Ling, S. M., and Liu, Shih-hao, Studies on plasma lipoids.
I. Fatty acids of blood plasma in diabetes and nephrosis. Chinese J. Physiol., 1928, 2, 157.

Maxwell, J., The blood cholesterol in nephritis. Quart. J. Med., 1927-28, 21, 297. Quart. J. Med., 1934, 3 (n. s.), 79.

Murphy, F. D., Chronic nephritis with and without edema : A study of cholesterol in these conditions. J. Clin. Invest., 1927, 5, 63.

Page, I. H., Kirk, E., Lewis, W. H., Thompson, W. R.', and Van Slyke, D. D., Plasma lipids of normal men at different ages. J. Biol. Chem., 1935, 111, 613.

Peters, J. P., and Van Slyke, D. D., Quantitative Clinical Chemistry. Volume I. Williams and Wilkins Co., Baltimore. 1931, p. 238.

Port, F., Uber Cholesterinämie bei Nephropathien. Deutsches Arch. f. klin. Med., 1919, 128, 6.

Schwarz, H., and Kohn, J. L., Studies of nephritis in children. I. Nephrosis. Am. J. Dis. Child., 1922, 24, 125.

Van Slyke, D. D., Page, I. H., Kirk, E., and Farr, L., Nature of nitrogenous constituents in petroleum ether extract of plasma. Proc. Soc. Exp. Biol. and Med., 1935, 32, 837.

Van Slyke, D. D., Stillman, E., Möller, E., Ehrich, W., McIntosh, J. F., Leiter, L., MacKay, E. M., Hannon, R. R., Moore, N. S., and Johnston, C., Observations on the courses of different types of Bright's disease, and on the resultant changes in renal anatomy. Medicine, 1930, 9, 257.

Westphal, K., Untersuchungen zur Frage der Entstehungsbedingungen des genuinen arteriellen Hochdruckes. IV. Cholesterin als tonogene Substanz der genuinen Hypertension im Zusammenspiel mit anderen Entstehungsbedingungen. Ztschr. f. klin. Med., 1924 25, 101, 585.

Widal, F., Weill, André, and Laudat, M., La lipémie des brightiques; rapports de la rétinite des brightiques aves l'azotémie et la cholestérinémie. Semana méd., 1912, 32,529 . 